\title{
Evolution and revolution: anarchist geographies, modernity and post-structuralism
}

\section{Federico Ferretti}

\author{
federico.ferretti@ucd.ie
}

This paper addresses the recent rediscovery of anarchist geographies and its implications in current debates on the 'foundations' of science and knowledge. By interrogating both recent works and original texts by early anarchist geographers who have greater influence on presentday literature such as Elisée Reclus (1830-1905) and Pyotr Kropotkin (1842-1921), I discuss the possible uses of a poststructuralist critique for this line of research by first challenging 'postanarchist' claims that so-called 'classical anarchism', allegedly biased by essentialist naturalism, should be entirely dismissed by contemporary scholarship. My main argument is that early anarchist geographers used the intellectual tools available in their day to build a completely different 'discourse', criticising the ways in which science and knowledge were constructed. As they openly contested ideas of linear progress, racism and European supremacy, as well as anthropocentrism and dichotomized definitions of 'man' and 'nature', it is hard to make them fit simplistic definitions. The body of work I address stresses their possible contributions to critical, anarchist and radical scholarship through their idea of knowledge, not limited to what is now called 'discourse analysis', but engaging with social movements in order to transform society.

Keywords

Anarchist geographies; More-than-human geographies; Evolutionism; Mutual Aid; Postanarchism

This paper addresses the connections between anarchist geographies and poststructuralist critiques of the anarchist tradition. According to Simon Springer, in the past few years 'a new generation of geographers has been stretching the boundaries of radical geography by placing anarchism at the centre of its practices, theories, pedagogies and methodologies' (Springer, 2016:26), at the same time laying claim to anarchist geographies' roots and genealogies, including figures such as Pyotr Kropotkin (1842-1921) Elisée Reclus (1830-1905), Lev Mečnikov/Léon Metchnikoff (1838-1888) and others (Pelletier, 2013; Springer, 2016). Today, 2017 "Evolution and revolution: anarchist geographies, modernity and post-structuralism", Environment and Planning D-Society and Space, DOI: 10.1177/0263775817694032. Online first: http://journals.sagepub.com/doi/full/10.1177/0263775817694032 
geographers generally acknowledge that 'anarchism may be the only major political movement that can claim to have geography and the ideas of geographers right at its centre' (Cresswell, 2013:52). Though acknowledging the importance of 'exploring from [an anarchist] geographical perspective' (Springer, 2016:42) poststructuralist critical tools, this paper challenges the dismissal of the aforementioned 'roots and genealogy' by a part of poststructuralist critique, namely the literature on so-called 'postanarchism' or 'poststructuralist anarchism' (Newman, 2001, 2010, 2011 and 2016; Day, 2005; Call, 2003; May, 1994; Rousselle, 2014), which draws on specific interpretations of thinkers like Michel Foucault, François Lyotard, Jacques Derrida, Gilles Deleuze and Félix Guattari.

Within critical scholarship, the references to these French authors are countless, heterogeneous and not new; nevertheless, a characteristic of 'postanarchism' is a hasty, and sometimes violent, dismissal of so-called 'classical anarchism', considered outdated and unfashionable. The work of very different figures like Kropotkin and Murray Bookchin (1921-2006) is likewise labelled 'essentialism' and a 'positivist approach' (Newman, 2016:6), and the entire anarchist tradition is side-lined by arguing that "classical anarchism as a theory of revolution no longer has any great relevance' (Newman, 2001:166). Below I challenge such statements, drawing on the relation between anarchism, geography and science as addressed by Kropotkin, Reclus and Metchnikoff, who still inspire present-day anarchist geographies. As 'science', I consider Pierre Bourdieu's sociological definition of 'scientific field' (1975), addressing early anarchist geographers' strategies to deal with it as it was configured in their day.

My main argument is that early anarchist geographers built an intellectual discourse completely different to the (essentialist) invention, by postanarchist authors, of an anarchist tradition 'embedded in the naturalist and essentialist philosophy of the nineteenth century' (Kuhn, 2009: 20), basically 'dialectical, materialist ... evolutionary' (Newman, 2010:51), and generally prone to 'linear progress' and anthropocentrism. Analysing a corpus of original texts from Reclus and Kropotkin on progress, science and on the relation between 'humankind' and 'nature', I show that these definitions cannot fit anarchist geographers, and cannot be generalised to so-called 'classical anarchism'. My aim is not to deny the interest of poststructuralist approaches for anarchist geographies, which is also acknowledged by authors like Springer (2012 and 2016), but 2017 "Evolution and revolution: anarchist geographies, modernity and post-structuralism", Environment and Planning D-Society and Space, DOI: 10.1177/0263775817694032. Online first: http://journals.sagepub.com/doi/full/10.1177/0263775817694032 
simply to show that the charge of essentialism and foundationalism cannot be attributed to anarchist geographers such as Reclus and Kropotkin. These geographers' writings on evolution and revolution questioned essentialising visions of 'humankind and nature' and provided some original definitions of what is now understood as the connection between structure and agency, matching a contemporary interdisciplinary literature (Gibson-Graham, 2006; Lorimer, 2012; Demeritt, 2002 Latour, 2004; Haraway, 2008).

I would argue that the main contributions the anarchist tradition can provide for non-essentialist geographies today lie in the ideas of individuality and variety. The first concept has not to be confused with 'individualism' but should be intended as a focus on individuals' agency as the starting point of social transformation which characterised all the anarchist political schools including the communist ones, drawing on 'the Individual, the Commune and the Federation' (CNT, 1936; Puente Amestoy, 2013). A focus on individuals can be a way to counter essentialism, as Reclus's and Kropotkin's texts addressed below show. The second concept is expressed in the Reclus's works on evolution and revolution I mention below, where the geographer analyses the complexity of the 'myriads' of diverse phenomena that deserve to be studied avoiding both generalizations and abstract theorizations: this approach is characterised by transnationalism, multilingualism and empathy toward differences.

Analysing Reclus's and Kropotkin's texts, I consider recent scholarship addressing their archives and showing the collective character of their work (Ferretti, 2011), and works which discuss the relations between anarchism and poststructuralism showing that the anarchist tradition can give some useful insights to present-day debates instead of being merely buried (Antliff, 2010; Jun, 2012). In addressing the link between anarchist geographies and evolutionism, I draw on international literature questioning the uncritical attribution of racism and other evils to the idea of evolution (La Vergata, 2009) and arguing that anarchist interpretations of evolutionary science, such as mutual aid (Kropotkin, 1902), are completely antagonistic to mainstream evolutionism that drew on Malthusian ethics and the 'survival of the fittest' (Adams, 2015; Girón Sierra, 2003; Gould, 1997; Kinna, 2016; Morris, 2014). Understanding the complex international circulations and different versions of evolutionism (Livingstone, 2014) enables us to understand the radical originality of its anarchist interpretation, drawing on contextual and situated readings 2017 "Evolution and revolution: anarchist geographies, modernity and post-structuralism", Environment and Planning D-Society and Space, DOI: 10.1177/0263775817694032. Online first: http://journals.sagepub.com/doi/full/10.1177/0263775817694032 
of scientific movements, in order to put 'science in its place' (Livingstone, 2003). Thus, my approach is not limited to a 'discursive' analysis, but considers what Charles Withers defines as a ‘spatially sensitive social constructivism' (Withers, 2010:67).

In the first part of my paper, I analyse postanarchist critiques of 'classical anarchism' and some countercritiques that draw on anarchist geographies and anthropologies. In the second part, I address the question of science, progress and evolution in the work of Elisée Reclus. In the third part, I put Reclus's ideas on the evolutionary connections between humans and nonhumans, which challenged the 'modern' idea of human domination over 'nature', in the wider context of more-than-human geographies; in the fourth part, I analyse the critique of science that Pyotr Kropotkin articulated. And in conclusion, I stress the importance of these genealogies for presentday debates on anarchist geographies.

\section{Challenges to anarchism}

It is somewhat amazing to remark that anarchism was once declared dead by those who thought of it as primitive and antimodern, and that the same declaration is now made by those who consider it an expression of Enlightenment and modernity. In Antonio Gramsci's famous Notebook 25, the Italian Communist dismissed anarchism as a 'millenaristic' peasants' movement, comparing the anarchist Errico Malatesta (1853-1932), a figure recently rediscovered by a vibrant international literature (Levy, 2007; Turcato, 2015), to the mystic preacher Davide Lazzaretti (1833-1878): 'Peasants involved in Malatesta's process thought in the same way as the Lazzarettists', (Gramsci, 1975:2282). ${ }^{1}$ This judgement was echoed by Eric Hobsbawm, who considered anarchists 'primitive rebels' (Hobsbawm, 1959).

In the 1990s, the spread of poststructuralism in academia led to the opposite extreme, i.e., early anarchists were no longer romantic dreamers opposed to modernity, but full members of the modernist and essentialist project of 'Enlightenment humanism' (Day, 2005:134), or 'merely modern' (Call, 2002:65) thinkers. A problem with these contributions is that most of them completely overlook authors such as Reclus, Metchnikoff or Malatesta, inventing and dismissing a 'classical' tradition without really engaging with its original texts and historical praxes, and

\footnotetext{
${ }^{1}$ All quotes by Italian and French sources have been translated by the author

2017 "Evolution and revolution: anarchist geographies, modernity and post-structuralism", Environment and Planning D-Society and Space, DOI: 10.1177/0263775817694032. Online first: http://journals.sagepub.com/doi/full/10.1177/0263775817694032
} 
providing internalist readings of the history of ideas. In the aforementioned works by Newman, Day and May, Reclus and Metchnikoff are never quoted, Malatesta is sometimes mentioned but no textual reference to his writings is presented, and the use of primary sources by 'essentialist', 'humanist', 'naturalist', 'positivist' anarchists such as Proudhon, Bakunin, Kropotkin and Bookchin is generally very limited. On the contrary, texts by Foucault, Derrida, Lyotard, Deleuze, Guattari, Lacan etc. are widely quoted, taking for granted that they have overtaken the 'old stuff'. Newman argued that 'anarchism relies on essence: on the notion of an essential, natural human subjectivity; on there being a natural essence in social relations that will be able to take the place of the state, the place of the power. This idea of essence constitutes anarchism's point of departure, its place of resistance which is uncontaminated by power' (Newman, 2001:51). This statement poses two main methodological problems. First, it essentialises anarchism, without seeking to make sense of the myriad of authors and historical experiences that constituted the complex anarchist tradition (Turcato, 2015), which is not only an abstract philosophy, but an idea linked to real movements and their praxes. Second, no text is quoted to demonstrate that at least one 'classical' anarchist thinker ever declared belief in any 'natural essence' or 'uncontaminated place'. Likewise, Todd May argued that poststructuralism 'replaces traditional anarchism's a priori' (May, 1994:87) without saying in which texts 'traditional anarchists' make claims for an 'a priori'. That would indeed be surprising if we consider Kropotkin's open attacks on Kantism and metaphysics, and his explicit denial of the 'essence of things', which I discuss in the last section.

According to Kropotkin's biographer Matthew Adams, these authors' exclusive focus on texts and discourses without an historical contextualisation entails 'a lack of sensitivity to contextual issues' (Adams, 2015:6). If authors enlist history for their own agendas, it should be done with a clear historical methodology, e.g., without attributing 'class reductionism' (Day, 2005:145) to anarchists: it is enough to read only a few lines of Malatesta, Reclus, or Kropotkin to know how far from that position they stood (Turcato, 2015). Similar problems surround the mention of an alleged 'echo of post-Utopian classical anarchism' (Day 2005:151), which is attributed to authors like Michael Hardt and Toni Negri, who never claimed any anarchist identity and were never acquainted with concrete anarchist movements. According to Newman, a very heterogeneous list of authors such as Negri, Hardt, Badiou, Rancière and Agamben would have drawn 'upon a kind 2017 "Evolution and revolution: anarchist geographies, modernity and post-structuralism", Environment and Planning D-Society and Space, DOI: 10.1177/0263775817694032. Online first: http://journals.sagepub.com/doi/full/10.1177/0263775817694032 
of anarchism without acknowledging it' (Newman, 2010:104). This is not a question of parochial distinctions, but a methodological one: if a (valuable) author rejects an anarchist (or 'postanarchist') label, for others to attribute it against his/her will is simply untenable.

Some anachronisms are ironically raised by Brian Morris, who criticises the fact that 'Day even describes Kropotkin as the "first post anarchist". Kropotkin wasn't "post" anything: he was an anarchist' (Morris, 2014:146). Similar problems of historical contextualisation affect Newman's declaration (concerning anarcha-feminism) that 'this link between feminist struggles and the anarchist struggle against authority had traditionally been ignored by anarchists' (Newman, 2001:165); actually the link was only ignored by Newman, if we consider that traditions of anarcha-feminism date back to the nineteenth century and Reclus's French networks, and involve twentieth-century figures and movements like Emma Goldman, Lucy Parsons, Voltairine De Cleyre and the Spanish organization Mujeres Libres (Ackelsberg, 1991; Breitbart, 1978; Goldman, 1970; Nash, 1975). Newman also attributes to 'classical anarchism' elements historically belonging to other traditions, which may have influenced some anarchists but cannot be considered anarchist markers, arguing that today 'there is no longer a distinct centre of power, no symbolic Winter Palace to storm' (Newman, 2016:48), without considering that this point mainly characterised not anarchist, but Marxist and Jacobin imaginaries. The evolutionary model espoused by Reclus and Kropotkin was exactly the negation of this Jacobin idea of revolution.

Newman uses Lacan, Stirner, Foucault, Derrida, and Deleuze 'to theorise a nonessentialist outside to power' (Newman 2001:160) and challenges anarchist 'Manichean division between artificial and natural authority' in a 'Enlightenment humanist framework' (2001:38). However, the alleged essentialism of traditional anarchism is likewise an a priori. This is pointed out by several authors who consider postanarchism a 'superficial critique' (Kuhn, 2009:21) of anarchism. Morris, in particular, argues that postanarchism relies on authors "none of whom, it is worth noting, were anarchists. We are also joyfully informed that no contemporary activist has ever read the works of Bakunin, Kropotkin or Malatesta as they are deemed to be as oldfashioned as the novels of Charles Dickens' (Morris, 2008:134). Moreover, for Morris, the use of authors like 'Nietzsche, Heidegger and Wittgenstein... all political reactionaries' (2008:143) poses further problems. Although this criticism might be deemed 'dogmatic' by the authors 2017 "Evolution and revolution: anarchist geographies, modernity and post-structuralism", Environment and Planning D-Society and Space, DOI: 10.1177/0263775817694032. Online first: http://journals.sagepub.com/doi/full/10.1177/0263775817694032 
targeted, I argue that it should be taken seriously, because it poses the problem of the historical contextualisation of authors' works, strongly asserted in historical geography (Livingstone, 2003 and 2014), where not only discourses, but also practices matter. In the anarchist tradition, great importance has been attributed to the consistency between theory and life (Kropotkin, 1924; Malatesta, 2014), 'meaning that thought (anarchist geographies) is never separable from practice (geographies of anarchism)' (Springer, 2016:27). Thus, the fact that one discusses anarchism while overlooking Reclus and Malatesta and taking inspiration from Martin Heidegger, an author who endorsed Hitler's regime (Faye, 2006), is not unproblematic. According to Newman, 'as Heidegger would see it, we live in an age of metaphysical closure in which the notion of universal first principle is questionable' (Newman, 2001: 161), leading us to 'the death of place, the death of essentialist foundations' (2001:162). Again, this is not to say that only radicals are worth quoting, but that, as recent literature has addressed Reclus and Kropotkin in their places and contexts (Pelletier, 2013; MacLaughlin, 2015), more recent authors should also be considered from the point of view of their biographies to understand their political choices. As Newman sees it, Foucault, Derrida, Deleuze and Guattari followed a 'libertarian ethos' (Newman, 2010:105) and especially 'Foucault is a kind of anarchist [although] he would almost certainly have refused this label' (Newman, 2010:63), but the author does not explain why Foucault would have refused it. This would have entailed mentioning some aspects of Foucault's biography, like his support for the Ayatollah's regime in Iran (Eribon, 1993). According to Morris, 'Lyotard ended up ... supporting the right-wing Giscard d'Estaing in the French presidential election, while Foucault became an apologist for the reactionary Islamic clerics ... and came to renounce all aspirations for a new social order' (Morris, 2014:174-175). By quoting these statements, I don't intend to deny the importance of these authors' contributions to geographical scholarship, but to understand critically how their lives were sometimes far from the radical imagination often associated with their works. Foucault was neither an anarchist nor a radical activist. Whether good or bad, this must be considered before assuming automatically that his thought as a matter of course eclipses earlier antiauthoritarian critiques.

Some authors have also argued that several of Foucault's critiques of power are already laid out in classical anarchist literature. In the case of Kropotkin, Ruth Kinna recently addressed 'his critique of prisons, which he treated as a microcosm of the state' (Kinna, 2016:190). Unlike 2017 "Evolution and revolution: anarchist geographies, modernity and post-structuralism", Environment and Planning D-Society and Space, DOI: 10.1177/0263775817694032. Online first: http://journals.sagepub.com/doi/full/10.1177/0263775817694032 
Newman, arguing that Foucault had more complex visions of state and society 'than classical anarchists imagined' (Newman, 2010:62), Morris sarcastically observes that 'the close relation between power and knowledge' was recognised 'long ago before Foucault arrived on the intellectual scene... power has always been productive and through history there has been a symbiotic relationship between political domination and religious ideologies. Biopower is nothing new! Thus anarchists like Kropotkin were not so dumb as to fail to recognise that power... is productive, in that it produces prisons, propaganda, disciplined subjects, laws, ideologies... modes of resistance' (Morris, 2014:178). According to Kinna, postanarchism has provided 'important and insightful critiques. But the lenses that leading writers in these currents have used to examine Kropotkin are woefully distorting' (Kinna, 2016:200). About the alleged lack of a 'micropolitical ethic' (Newman 2010:161) in 'classical anarchism', recent work on the organisational anarchism of Malatesta show that the daily dimension of power was likewise not overlooked or ignored (Turcato, 2015). In the same vein, Springer stresses how Proudhon might have anticipated later ideas on biopolitics. 'The extent to which anarchist thought informs biopolitics is revealing. When Foucault began contemplating the application of political power on all aspects of human life .... it seems clear that French anarchist Pierre-Joseph Proudhon's philosophy on governance served as inspiration' (Springer, 2016:117). Anyway, if Foucault had such a debt, he never acknowledged it.

\section{Elisée Reclus: questioning science, evolution and progress}

Ideas, according to David Livingstone, are 'not conjured out of thin air' (Livingstone, 2010:15) because discourses exist in social, spatial and intellectual contexts. In this vein, recent research has addressed early anarchist geographers as a network that produced a consistent body of knowledge (Pelletier, 2013; Brun, 2015) while sharing places, material conditions (exile in Switzerland and political persecution) and common concerns with respect to both geography and politics. Reclus, Kropotkin, Metchnikoff and others were committed both to the redaction of the monumental New Universal Geography and to the construction of the Fédération jurassienne, the first anarchist organisation in history (Vuilleumier, 2012). The close relations between knowledge and power were clear to them: the aforementioned research showed their conscious strategy of entering the 'scientific field' (Bourdieu, 1975), targeting at the same time a broad audience for propaganda reasons. Study of the unpublished correspondence of the 1880s between 2017 "Evolution and revolution: anarchist geographies, modernity and post-structuralism", Environment and Planning D-Society and Space, DOI: 10.1177/0263775817694032. Online first: http://journals.sagepub.com/doi/full/10.1177/0263775817694032 
Reclus, Kropotkin and Metchnikoff, which is conserved in the State Archive of the Russian Federation, has shown that the theory of mutual aid, later popularised by Kropotkin, had been discussed and collectively elaborated by these scholars in Switzerland (Ferretti, 2011). This implies that their work on 'evolution and revolution' should be read in the context of their commitment to the construction of a public intellectual sphere challenging religions and other metanarratives, like the state and its control over schools and other places where knowledge was produced.

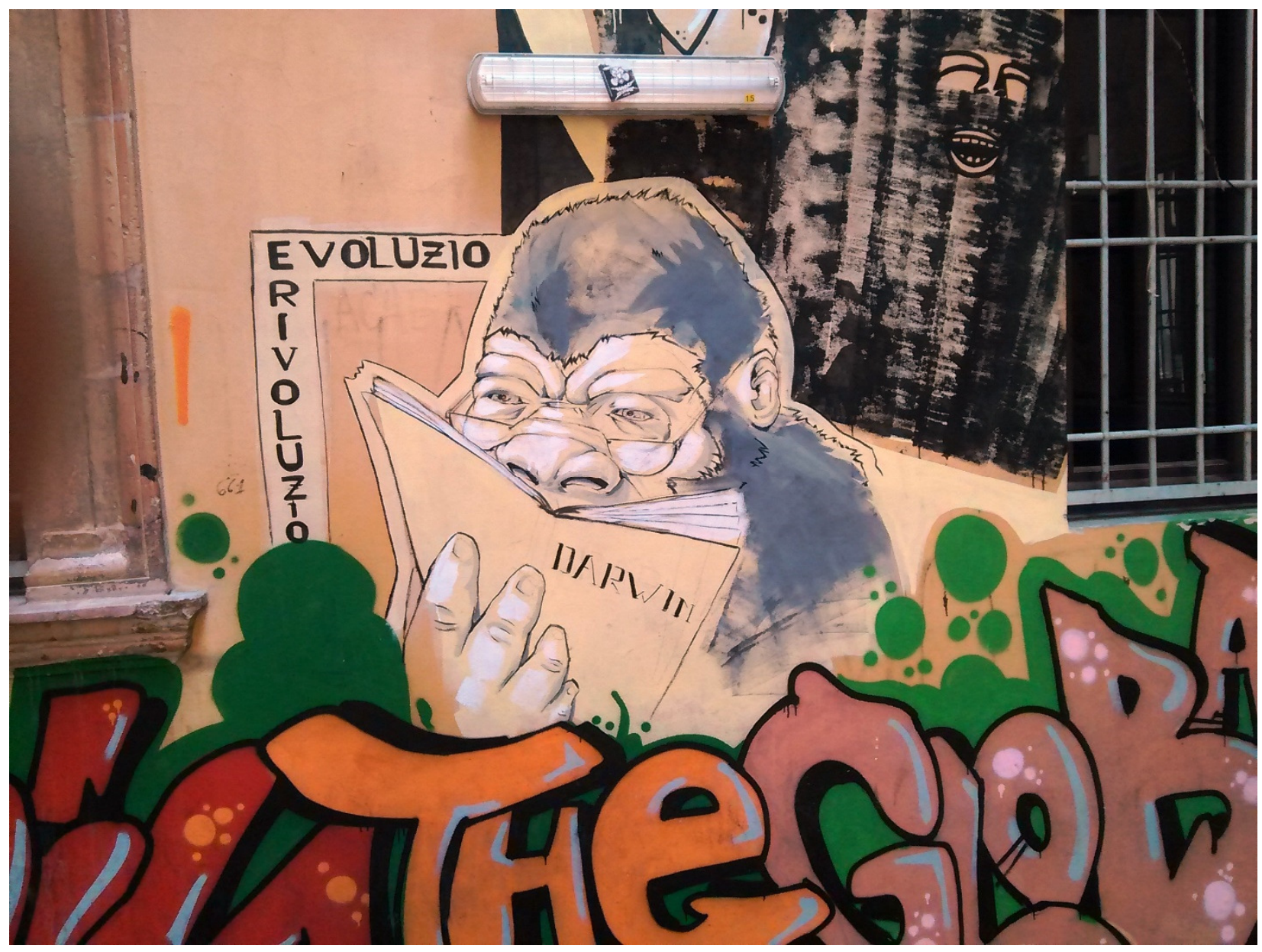

Fig.1. University of Bologna, August 2016 (photo by the author)

Within the militant debates of the time, the idea of mutual aid implied an original statement, i.e. that evolution and revolution were not two incompatible concepts, as set out by Reclus in 1881 in L'évolution, la révolution et l'idéal anarchique, and by Metchnikoff in his paper for the Contemporary Review (Metchnikoff, 1886), what seems less surprising today, including in street 2017 "Evolution and revolution: anarchist geographies, modernity and post-structuralism", Environment and Planning D-Society and Space, DOI: 10.1177/0263775817694032. Online first: http://journals.sagepub.com/doi/full/10.1177/0263775817694032 
art (Fig. 1). According to Reclus, 'Myriads and myriads of revolutions follow one another within the universal evolution; however minor they may be, they are part of this infinite movement. Thus, science sees no opposition in these two words — evolution and revolution — which are very similar, albeit used in a different sense in common language' (Reclus, 2012:10). This merging of evolution and revolution entailed the denial of the idea of linear progress, for which Reclus drew on the 'circularity' of history devised by the Italian philosopher Giambattista Vico (1688-1744).

Vico, in his Scienza Nuova, showed us human societies evolving through his series of Ages by corsi e ricorsi, that is, by a regular ebb and flow, creating circles in time and forever bringing back the same state of affairs following the end of the cycle. The concept is rather childish in its simplicity, and none of Vico's disciples managed to accept it without making some changes ... One prefers to use the term "spiral of civilization", whose endlessly expanding cycles have developed indefinitely over the Ages. However, it must be said that the shape of this spiral is hardly a geometrical one, and each event comes to change the direction of its curve (Reclus, 1905:344-346).

This quote shows how the anarchist geographers were far from the linear idea of progress, generally attributed to positivism, as Adams already notes for Kropotkin's not linear, but 'serpentine vision of historical progress' (Adams, 2015:81). According to Reclus: 'In the rhythmic succession of events, the ebb and flow assume such a scale and merge in such a varied way that it is impossible to recognise them with certainty; and to a great extent it is to see them neatly arranged that the plane figure on which Vico's scales move has been replaced by a limitless curve with ascending turns. This is a poetic image which Goethe loved; nevertheless, it presents only a very distant correspondence to reality... geometrical forms, however elegant, are not enough to give an idea of his endless undulations' (Reclus, 1908:526). This statement of the impossibility of a geometric modelling of the world was part of what today we might call a Reclusian critique of representation, which the French anarchist geographer translated into practical terms through his criticism of flat maps (Ferretti, 2014), anticipating some features of successive studies of 'cartographic reason' (Olsson, 1987).

According to Reclus, the solidarity between the different forces of oppression led to the subsequent solidarity of freedoms. This anticipated the present-day concept of intersectionality, aiming 'to understand the ways in which class intersects with other social cleavages, with very different e/affects' (Wills, 2008:28), as well as the multiplicities of scales and dimensions of 2017 "Evolution and revolution: anarchist geographies, modernity and post-structuralism", Environment and Planning D-Society and Space, DOI: 10.1177/0263775817694032. Online first: http://journals.sagepub.com/doi/full/10.1177/0263775817694032 
power. 'All forms of social progress are interdependent, and we long for all of them according to our knowledge and energy: social and political progress, moral and material progress in science, art, or industry' (Reclus, 2012:15). These lines match present-day scholarship challenging 'single axis' approaches and the 'false dichotomy between the particular and the universal' (Cho, Crenshaw and McCall, 2013:801) in order to inform 'connections across privilege as well as subordination to better facilitate meaningful collaboration and political action' (2013:803). Reclus is explicitly evoked as a pioneer of intersectional approaches by Richard White, arguing that his work can inspire today 'activists working to advance an intersectional politics of Total Liberation' (White, 2015:191) and that 'a commitment to an intersectional politics ... has a natural alignment with anarchist praxis' (2015:196). The same concept is expressed by John P. Clark, who notices that Reclus and Kropotkin 'explored the intersection between the natural and the social' (Clark, 2013:16) arguing that Reclus 'anticipates the present analysis, in which the system of domination is seen as consisting of specific forms of domination that function through the dialectical interaction of social institutional structures, the social ideology, the social imaginary, and the social ethos' (2013:95).

Like Kropotkin, Reclus criticised science and knowledge, relativising these tools while being nonetheless committed to using them for his social undertaking. This position implied a full democratisation of them. 'We want to know. We do not grant that science is a privilege, and that men perched upon a mountain like Moses or a throne like the Stoic Marcus Aurelius, or simply in a university chair can dictate laws to us while boasting of their superior knowledge of the eternal laws' (Reclus, 2012:43). The categories of essentialism and foundationalism can hardly be applied to militants and scholars who seemed to be aware of the ideological nature of knowledge. 'Yet political economy, that alleged science, has taken over the legacy of religion and in turn preaches that dire poverty is inevitable and society is not to blame if destitute wretches succumb to hunger' (2012:64). Almost a century before Foucault, Reclus criticised the use of science for policing and social control, inspired by authors like the Italian positivist Cesare Lombroso, who considered anarchists 'born criminals' according to anthropometric measures of the day. 'One starts by measuring true or alleged criminals, then one measures the suspects, and some day eventually everybody will have to submit to the infamous photographs. The police and science are locked in a long embrace' (Reclus, 2012:83). Some pages from Discipline and Punish seem 2017 "Evolution and revolution: anarchist geographies, modernity and post-structuralism", Environment and Planning D-Society and Space, DOI: 10.1177/0263775817694032. Online first: http://journals.sagepub.com/doi/full/10.1177/0263775817694032 
to echo these statements, for instance when Foucault addresses the scientific invention of delinquency: 'It is said that the prison fabricated delinquents ... it also fabricates them in the sense that it has introduced into the operation of the law and the offence, the judge and the offender, the condemned man and the executioner [and] caught them in the same trap. The penitentiary technique and the delinquent are in a sense twin brothers' (Foucault, 1991:255).

It is also worth noting that anarchist intellectuals belonged to a political movement largely composed by self-educated proletarians, as highlighted by invaluable biographical dictionaries (Angaut et al., 2014; Antonioli et al., 2003-2004), which explains the anarchist geographers' commitment to public education for both children and adults, targeting a programme of social emancipation. This is an important point for my argument. Here lies their challenge to what postanarchists call voluntary servitude, drawing on Etienne de la Boétie (Newman, 2016), but forgetting early anarchist critiques of the concept. As Reclus argued, 'Social science teaches us the causes of servitude and indirectly the means for liberation' (Reclus, 2012:34). That is, the movement for anarchist education sought to allow all individuals building their own critical instruments in order to deploy not obedience but active agency throughout their lives (Springer, White and Souza, 2016).

Anarchist geographers did not make major distinctions between the lowest and 'expert' levels of knowledge; their challenge was to fully democratise the 'scientific field'.

With or without schools, every great conquest of science eventually makes its way into the public domain... Of course some of the privileged would like to keep science's benefits for themselves and leave ignorance for the people: every day industrialists appropriate this or that chemical process and, by a patent, assume the right to solely produce this or that thing useful to mankind... but too many researchers are hard at work for selfish desires to become reality. These exploiters of science find themselves in the same situation as that magician in The Thousand and One Nights who unsealed the jar where the Genie of the Lamp had been sleeping for ten thousand years. They would like to get him to return to his tiny nook, shut him up under triple seal, but they have lost the magic word and the genie is forever free. (Reclus, 2012:112-113)

Subaltern agency (for this concept see Featherstone and Griffin, 2016) was thus early anarchist geographers' answer to the problem of the commodification of knowledge.

2017 "Evolution and revolution: anarchist geographies, modernity and post-structuralism", Environment and Planning D-Society and Space, DOI: 10.1177/0263775817694032. Online first: http://journals.sagepub.com/doi/full/10.1177/0263775817694032 
Reclus's criticisms of the scientific field drew on social and political uses of knowledge in official institutions led by mandarins and adopting what Reclus considered an aberration, i.e. 'national science'. 'One need not believe that all scientists are heroes... one is often astonished to notice an extraordinary contrast between their genius, or at least their great knowledge, and their ridiculous petty traits like passion, private interest, base sycophancy ... the survival of national hatreds' (Reclus, 1908:429). Reclus analysed the links between knowledge and power in his critique of both the Saint-Simonist tendencies, which were similar to what is called 'technocracy' today, and the political outcomes of Auguste Comte's positivism, waxing ironic about scientific claims of 'infallibility', the traditional self-attribution of religious leaders.

While some scientists are exalted in serving their master, others claim to be the masters themselves. For a while, under the influence of the primitive socialism of the Saint-Simonists and the Comtists, an article of faith seemed to prevail: like a large factory discreetly run by engineers, society had to be managed... by technicians and artists, i.e. the leaders of the new schools, striving for infallibility ... It is clear though that once established in ruling classes and castes like Chinese mandarins, the greatest scientists of Europe in their respective disciplines would be just as bad princes as all other rulers. (Reclus, 1908: 430)

Analysis of capitalist uses of science led to an early critique of scientific paradigms and possibilities (concepts only later defined by Carl Popper, Thomas Kuhn and others) in the context of an anarchist critique of 'scientific fictions', challenging what today we could call the 'metanarratives' of capitalism, state, religion and academia. 'Science', as I explain in the last section, was not intended as a foundation, but more likely as a method allowing for free and horizontal contributions from everybody, providing alternatives to elitist academism which still seem worthy of consideration today. For Reclus, no paradigm can be explained outside of its material and social implications, which implies a critique of every supposed scientific 'foundation'. 'What a difference between free science, a source of camaraderie, and science that has been put in the service of industry and profit, for instance in those factories ... where chemists work side by side in closed compartments, forbidden to communicate the result of their analyses to one another and unaware of the ultimate aim of the research' (Reclus, 1908:457-458).

2017 "Evolution and revolution: anarchist geographies, modernity and post-structuralism", Environment and Planning D-Society and Space, DOI: 10.1177/0263775817694032. Online first: http://journals.sagepub.com/doi/full/10.1177/0263775817694032 
Reclus also challenged a Eurocentric and uniform vision of 'progress', in the context of his critique of colonialism, racism and ethnocentrism (Ferretti, 2016). Alleged European superiority was ridiculed by stressing the social contradictions of so-called civilised societies. "No "savage" tribe dwells in such hell-holes: Glasgow, Dundee, Rouen, Lille' (Reclus, 1908:534). Progress, for Reclus, was not an 'essentialist', but a relative and relational concept, considering the difference of standpoints. 'Taken in an absolute sense, the word progress has no meaning at all, as the world is infinite and, in the boundless vastness, one remains forever just as far from the beginning as from the end' (Reclus, 1908:501). Reclus was for neither positivism nor absolute relativism, but closer to what we might call a situated subject (Haraway, 1988). In this sense, he challenged the conservatives and European chauvinists who denied the possibility of a general progress of all humankind, making clear that this was not a naïve faith in a linear pathway toward a (White and European) standard, but precisely a challenge to this standard and its alleged intangibility for the Other. 'Change is thwarted according to how close or far it is to the particular degree occupied by the observer on the scale of beings. The missionaries who meet magnificent savages freely going about in their nakedness believe they are helping them to "progress" by distributing dresses, shoes, hats, and catechisms' (Reclus, 1908:503). Finally, 'the word civilisation that one normally employs to define the progressive state of this or that nation is like the term progress, one of those vague expressions whose different meanings merge' (1908:504).

Consistent with the ethnographic works of his brother Elie Reclus (1827-1904), Elisée Reclus refused to consider so-called 'primitives' as having 'progressed' less, and even argued that some groups of hunter-gatherers like the Negritos of the Philippines, albeit almost exterminated by later conquerors, ought to be considered the inspiration for the theory of Mutual Aid.

Among the peoples that must clearly be set high up among the men who come closest to the ideal of mutual aid and love, we must indeed number a tribe classified among the primitives, the Atta... Members of the tribe feel as though they are all brothers... the sick, children, and the old are cared for with perfect devotion; nobody exercises power, yet they willingly defer to the experience and the moral authority of the elder. Is there a single nation in Europe or America to which one can address such high praise? (Reclus, 1908:510)

These statements fit present-day scholarship on anarchist anthropologies which addresses the institutions of stateless peoples not as markers of backwardness but as solutions worthy of 2017 "Evolution and revolution: anarchist geographies, modernity and post-structuralism", Environment and Planning D-Society and Space, DOI: 10.1177/0263775817694032. Online first: http://journals.sagepub.com/doi/full/10.1177/0263775817694032 
consideration when imagining anti-authoritarian societies (Scott, 2009; Barclay, 1996; Morris, 2014; Graeber, 2004). Elisée Reclus's final calls for the 'complete union of the civilised with the savage and with nature' evinces an effort to avoid not only ethnocentrism, but also anthropocentrism.

The social question arises again and to its full extent. It is impossible to wholly love the primitive savage, if one does not love the people of the more or less artificial society of the contemporary world. How is one to admire the modest, charming individuality of the flower, feel a brotherhood with the animal... when one does not see humans as dear comrades as well?...The complete union of the civilised with the savage and with nature can only be realised through the destruction of the borders between peoples. Every individual, without obeying ancient conventions and habits, must be able to speak to any of his peers in full brotherhood and talk freely with him about "everything that is human", as Terence said. (Reclus, 1908:538)

This reference to Terence's motto homo sum, suggest an idea of humanism not as anthropocentrism, but as planetary solidarity, one mainly opposed to Max Stirner's egoism and the Nietzschean 'superman' (1908:539), other concepts enrolled in postanarchism, but which were, for anarchists like Reclus, just philosophical justifications of inequality.

\section{More-than-human anarchist geographies}

Contemporary critiques of the concept of humanism, sometimes set against 'naturalism' and sometimes merged with it, pose the problem of defining these terms. Newman argues that 'classical anarchism' has 'its foundations in the discourses of Enlightenment humanism and rationalism' (Newman, 2011:316), while Day quotes the concept of 'modernist' and 'rationalistic humanism' (Day, 2005:95) as the unconditional human domination of nature. However, no clear 'postanarchist' alternative to anthropocentrism is apparently stated.

Reclus's ideas of dynamic relations between humankind and 'nature' as consubstantial entities, not existing in a pure state but as 'hybrids' (Swyngedouw, 2006), can be read in the critical terms of recent geographical scholarship addressing the concept of the Anthropocene and challenging what Jamie Lorimer defines as 'the modern understanding of Nature as a pure, singular and stable domain removed from and defined in relation to urban, industrial society' (Lorimer, 2012:593). I would argue that Reclus's works provide insights for contemporary geographers who are

2017 "Evolution and revolution: anarchist geographies, modernity and post-structuralism", Environment and Planning D-Society and Space, DOI: 10.1177/0263775817694032. Online first: http://journals.sagepub.com/doi/full/10.1177/0263775817694032 
developing a 'critique of linear, cyclical, reversible and orderly temporalities to offer a range of concepts that affirm the creative, non-linear, irreversible and open-ended nature of time' (2012:596). If mobilizing concepts like rhizome or flat ontology would be anachronistic in the case of Reclus and Kropotkin, it is true that they provided elements of complexity which recall contemporary 'multinatural geographers advocat[ing] context-specific forms of posthumanist ethical and political responsibility that emphasise respect for the radical alterity and unpredictability of organisms, their ecologies and the multiple constituencies who have a stake in their conduct' (2012:604). If, according to Lorimer, 'further empirical and theoretical work is required to draw more-than-human work together, to map and compare relations and to reflect upon the possibility of general frameworks for multinatural environmental politics' (2012:605), reading Reclus can furnish important insights for contemporary debates. The anarchist geographer was an early supporter of what is called today 'animal rights' (Pelletier, 2015), being a vegetarian and justifying this choice in moving passages on his idea of the solidarity between humans and nonhumans (Reclus, 1901). White acknowledges Reclus as inspirer of 'an expanded anarchist geographical praxis that embraces more than human animals when speaking of ethics and social justice' (White, 2015:192) including aspects of everyday violence at the micro scale in the connection between abuses on animals and abuses on persons. Several authors from different perspectives have stressed both how his environmental sensibility (Clark, 2013; Clark and Martin, 2013; Dunbar, 1978) and his radical critique of what is now called the "commodification of nature' (Castree, 1995). A part of Reclus's training on these topics stemmed from German Naturphilosophie (Tang, 2008), and merging the latter with Darwinism, the anarchist geographer reached conclusions similar to topics now addressed by the more-than-human geographies (Philo and Wilbert, 2000). Reclus could hardly be defined as a supporter of human supremacism.

Reclus also used definitions that are akin to the contemporary one of 'human and nonhuman animals'.

The animal world to which we belong and which we extend has become our great educator; it offers valuable examples for every one of life's acts... If man, an animal himself, had been troubled by the arts of fishing, hunting or gathering, hadn't there been a number of examples going on around him that he might have followed? On the beach, crabs and other crustaceans show the places where to find 'seafood' in the sand or mud. Every animal searching for

2017 "Evolution and revolution: anarchist geographies, modernity and post-structuralism", Environment and Planning D-Society and Space, DOI: 10.1177/0263775817694032. Online first: http://journals.sagepub.com/doi/full/10.1177/0263775817694032 
mast, grubbing up roots, foraging, chasing fish, was carefully observed by the starveling, and he then tasted the different foods ... which served as nourishment for his close brothers. (Reclus, 1905:135)

Reclus envisaged relations between animal agency, animal geographies and early human historical geographies. 'Man', he argued,

is infinitely indebted to his animal ancestors for the art of choosing a dwelling or building a shelter. Many a cave would have remained unknown, if he had not seen bats flying around the rock fissure behind which opens the secret door of underground galleries. A wealth of good ideas were likewise provided by the nest-building bird, so deft at weaving fibres, tufts of wool and hairs, and even at sewing leaves... Now we are imitating the birds to build airships in the same way we once imitated fish to fashion skiffs with a backbone serving as a keel, and fish bones becoming ribs and fins transformed into paddles and oars (1905:137-138).

And like Kropotkin, Reclus acknowledged the role of animals as examples of mutual aid.

Imitation often merges with mutual aid... When Darwin, Wallace and their emulators had so admirably laid out the system of organic evolution through adaptation of beings to their environment, most of their disciples... allowed themselves to be seduced by a simplistic hypothesis, seeing only the 'struggle for existence' in the infinite drama of the living world. However, the renowned author of On the Origin of Species and The Descent of Man had also addressed the 'agreement for existence'. ... Yet how many alleged Darwinists wanted to completely ignore all the facts of mutual aid and angrily scream and shout, as if the sight of blood excited them to murder: 'The animal world is a gladiators' arena... every creature is trained for combat!' And under the cloak of science, how many violent and cruel people found themselves suddenly justified in their acts of selfish appropriation and brutal conquest! $(1905: 140-141)$

If ethics is a fundamental point in anarchist thinking (Kinna, 2016), Reclus acknowledged it as an attribute of nonhuman individuals, also showing that he was a far cry from essentialising the human nature as 'good'.

Among animals, solidarity extends as far as goodness and devotion, such as humans conceive and practice themrarely, moreover ... Whatever one may say, the struggle for life is not the law par excellence, and agreement prevails far and away in the history of the development of beings. We are provided the best proof by the fact that the species that are the most fortunate in their destiny are not the best equipped for plunder and murder, while on the contrary those which are endowed with rather paltry arms are most eager to help each other: they are not the most ferocious, but the most loving. (1905:144)

2017 "Evolution and revolution: anarchist geographies, modernity and post-structuralism", Environment and Planning D-Society and Space, DOI: 10.1177/0263775817694032. Online first: http://journals.sagepub.com/doi/full/10.1177/0263775817694032 
These statements clearly reveal that anarchist geographers, far from seeing human and nonhuman beings as hostages of mechanical 'laws of nature', viewed them as protagonists with agency, feelings and freedom. That is, mutual aid was a choice among several alternatives and not a deterministic concept (Metchnikoff, 1889). Reclus's ideas offer obvious parallels with the work of Kropotkin in his empathy toward the animal world, which has been underscored by Lee Dugatkin (2011), and which the Russian thinker admitted himself, writing that the 'example of animals' (Kropotkin, 1899:251) prepared him to become an anarchist. As Hayden Lorimer notes, 'Peter Kropotkin's theses on mutual aid as a factor in evolution' are still used to argue that animals are 'capable of insight' (Lorimer, 2006:500) by scientists willing to question anthropomorphism, who consider it odd 'for scientists to perpetuate their zoological diminution of animal experience' (2006:501).

\section{Kropotkin: anarchy as an antimetaphysical method}

The 'culture wars' (Mitchell, 2000:14) that anarchist geographers engaged in the scientific field of their time against religions, state ideologies, social Darwinism and mainstream positivism show that nineteenth- and twentieth-century European science was not a monolith but rather an arena where rich debates and radical contrasts existed. Kropotkin consciously mobilised 'scientific' tools for his political ends, including, in his defining of mutual aid, 'using Lamarck to rid the scientific field of Malthus' (Girón, 2005:137). As Adams observes, Kropotkin used some aspects of positivism instrumentally, 'in making knowledge coherent: recording, cataloguing and tracing connections' (Adams, 2015:74), albeit 'the narrative he presented clearly did not offer a story of steady progress' (2015:83). According to Morris, if humanism means 'the human domination of nature by means of technological mastery, then, most certainly, Kropotkin was not a humanist. Neither was he a philosophical rationalist' (Morris, 2014:184).

In Modern Science and Anarchism, Kropotkin's attempt to use science without illusions appears clearly in his comparison between the advent of anarchism and the affirmation of natural science, as he strives to explain why he merged anarchy and experimental sciences to enhance social transformation. Although some statements can sound outdated today, it is clear from reading Kropotkin's original text that this kind of 'scientific anarchism' was intended as a method, not as 2017 "Evolution and revolution: anarchist geographies, modernity and post-structuralism", Environment and Planning D-Society and Space, DOI: 10.1177/0263775817694032. Online first: http://journals.sagepub.com/doi/full/10.1177/0263775817694032 
a vast 'foundation'. Its aim was not to determine a linear pathway, but to reject metaphysics, dialectics and anthropomorphism. Positivist authors such as Herbert Spencer and Auguste Comte are thoroughly criticized by Kropotkin, who warned his reader that science is only one of the possible instruments for achieving social goals.

It would be unreasonable, therefore, to expect of the young social sciences, which are concerned with phenomena much more complex than winds and rain, that they should foretell social events with any approach to certainty. Besides, it must not be forgotten that men of science, too, are but human, and that most of them either belong by descent to the possessing classes, and are steeped in the prejudices of their class, or else are in the actual service of the government. Not out of the universities, therefore, does Anarchism come. As Socialism in general, Anarchism was born among the people; and it will continue to be full of life and creative power only as long as it remains a thing of the people. (Kropotkin, 1903:5)

To relativise science, it is necessary to consider its political meaning within a certain context. In Kropotkin's day, using a 'natural inductive and deductive method' meant first critically recovering the legacy of the French revolution and challenging the following Restoration. The example Kropotkin furnished was that of the physicist and mathematician Laplace, who 'constructed his system without metaphysics... The French eighteenth-century philosophers did exactly the same with regard to the phenomena of the spiritual world. In their writings one never meets with such metaphysical statements as are found, say, in Kant' (1903:14). Rebutting metaphysics meant that the sources of ethics were not the divine or other metanarratives, but the concrete behaviour of beings. Kropotkin did not propose any theoretical system or 'grand narrative'. 'Obscure terms like "the categorical imperative", or "universal law" ... do not explain anything. The merit of such a treatment is self-evident. Instead of the "inspiration from above" and a superhuman, miraculous origin of the moral sense, they dealt with the feeling of pity, of sympathy derived by man through experience and inheritance, and subsequently perfected by further observation of social life' (1903:15-16).

In his historical review, Kropotkin showed himself to be aware that 'objectivity' is a concept dependent on scientific paradigms and their conditions of possibility, i.e. political or religious pretexts for defining what we can consider science or not. "Under the pretext of "studying facts" and "gathering scientific material", even such exact measurements as the determination of the 2017 "Evolution and revolution: anarchist geographies, modernity and post-structuralism", Environment and Planning D-Society and Space, DOI: 10.1177/0263775817694032. Online first: http://journals.sagepub.com/doi/full/10.1177/0263775817694032 
mechanical power necessary for obtaining a given amount of heat... were set aside by the scientists... on the ground that they were "unscientific", (1903:22). According to Kropotkin, the new scientific paradigms paralleled socialism because the revolutions of 1848 and the rise of socialist and libertarian movements enabled the individual freedom to pursue scientific research. Thus, 'science' meant first individual freedom and the establishment of a public sphere independent from governmental control. To understand Kropotkin, we should take seriously the struggle between the freedom of research, on the one hand, and states and churches, on the other, instead of tossing the respective positions in the same 'essentialist' and 'positivist' pot. Kropotkin denounced asylums as places where dissidents were confined: 'for such heretical views the naturalists had to reckon with prison, torture, or the lunatic's asylum... It was a fierce battle, but, owing to the support of the masses of the public, the victory was won, nevertheless, by the Darwinians' (1903:35). The philosophical aims expressed by Kropotkin also show that giving up 'essences' is not a poststructuralist invention: 'A philosophy which, no longer discussing "the essence of things", "first causes", the "aim of life", and similar symbolic expressions, and repudiating all sorts of anthropomorphism (the endowment of natural phenomena with human characteristics), should be a digest and unification of all our knowledge' (1903:25-26).

If the socialist and anarchist world at that time often used expressions such as 'positive science' in opposition to religions, Kropotkin explicitly criticised the 'apostles of positivism' Comte and Spencer. About Comte, Kropotkin discussed the reasons of the metaphysical 'degeneration' of his thinking, 'In lieu of the God of all religions, whom man must worship and to whom he must appeal in order to be virtuous, he placed Humanity, writ large. To this new idol he ordered us to pray... the ritualism of Comte's religion moulded itself very naturally upon the model of all the preceding positive religions' (1903:29). One of Comte's mistakes, according to Kropotkin, was not having considered the materiality of humans as being opposed to metaphysics; thus, he still needed some kind of divine metanarrative, i.e. god. 'He did not see that the moral sentiment... had made its first appearance in the animal societies which existed long before man had appeared upon earth' (1903:29).

As for Spencer, Kropotkin regretted that the Positivist author did not push his liberal thinking to its (extreme) logical conclusion by getting rid of the state as the basis of social organisation. 2017 "Evolution and revolution: anarchist geographies, modernity and post-structuralism", Environment and Planning D-Society and Space, DOI: 10.1177/0263775817694032. Online first: http://journals.sagepub.com/doi/full/10.1177/0263775817694032 
Kropotkin's analysis matches here recent scholarship on nonstatist geographies (Ince and Barrera, 2016; Springer, 2014). 'Spencer's synthetic philosophy ... still contains in its sociological part mistakes as gross as are found in [Comte's] work' (Kropotkin, 1903:40). According to Kropotkin, Spencer's philosophy was also incapable ridding itself of ethnocentrism: 'The history of the Englishmen's relations with the "lower races" is full of like misunderstandings. [Spencer] is quite incapable of understanding the customs and ways of thinking of the savage, the "blood revenge" of the Icelandic saga, or the stormy life, filled with struggles, of the mediaeval cities. The moral ideas of these stages of civilisation are absolutely strange to him; and he sees in them only "savagery", "despotism" and "cruelty" (1903:42). This mirrors Reclus's and Metchnikoff's denial of the existence of 'inferior races' (Metchnikoff, 1889:98; Reclus, 1888:554) founded on 'scientific' bases and drawing on peoples' different adaptations to environment, which rendered impossible absolute (or 'essentialist') judgements.

Considering the materialist and evolutionary nature of the relations between humans and nonhumans, Kropotkin contested the racist and ethnocentric prejudices against so-called primitives which characterised evolutionists like Thomas Huxley.

Following Hobbes, all the philosophy of the nineteenth century continues to look upon the savages as upon bands of wild beasts which lived an isolated life and fought among themselves over food and wives, until some benevolent authority appeared among them and forced them to keep the peace. Even such a naturalist as Huxley advocated the same views as Hobbes, who maintained that in the beginning people lived in a state of war, fighting 'each against all', till, at last, ... the 'first society' was created ... Even Huxley, therefore, failed to realize that it was not Man who created society, but that social life existed among animals much earlier than the advent of man (Kropotkin, 1903:45).

This appears to be a far cry from Day's references to an undifferentiated scientific faith in 'cultural essentialism and genocidal integration into European modernity' (Day, 2005:87). Kropotkin's anarchism does not look like a foundation, but like a method in-becoming:

'Anarchism is a world-concept based upon a mechanical explanation of all phenomena [Kropotkin's note reads: 'It would be ore correct to say, a kinetic explanation, but this word is not so commonly known'] embracing the whole of Nature - that is, including in it the life of human societies and their economic, political, and moral problems... In the domain of philosophy of law, in the theory of morality, in political economy, in history... Anarchism has already shown that it will not content itself with metaphysical conclusions, but will seek in every case a natural-scientific 2017 "Evolution and revolution: anarchist geographies, modernity and post-structuralism", Environment and Planning D-Society and Space, DOI: 10.1177/0263775817694032. Online first: http://journals.sagepub.com/doi/full/10.1177/0263775817694032 
basis. It rejects the metaphysics of Hegel, of Schelling, and of Kant; it disowns the commentators of Roman and Canon Law, together with the learned apologists of the State; it does not consider metaphysical political economy science (Kropotkin, 1903:53-54).

On the contrary, scepticism toward foundationalist metaphysics characterises Kropotkin's anarchism:

When the Anarchists are told, for instance, that-as Hegel says-every development consists of a Thesis, an Antithesis, and a Synthesis; or that 'the object of Law is the establishment of Justice, which represents the realisation of the Highest Idea'; or, again, when they are asked,-What, in their opinion, is 'the Object of Life?' they, too, simply shrug their shoulders and wonder how, at the present state of development of natural science, old-fashioned people can still be found who continue to believe in 'words' like these and still express themselves in the language of primitive anthropomorphism (the conception of nature as of a thing governed by a being endowed with human attributes)... The development of social life is incomparably more complicated ... than it would appear from such formulae. We have heard much of late about 'the dialectic method', which was recommended for formulating the socialist ideal. Such a method we do not recognise. (1903:55-56)

For Kropotkin, experimentalism was deemed a pragmatic answer to dogmatic knowledge based on metaphysics, by defining scientific laws as 'conditional', that is relational and relative. 'Every law of nature has a conditional character. It is always expressed thus: 'If certain conditions in nature meet, certain things will happen'. 'If one line intersects another ... the consequences will be these or those.... In every case there is an 'if' - a condition' (1903:70-71). Finally, anarchism is defined as nothing but an attempt: "Anarchism is an attempt to apply to the study of the human institutions the generalisations gained by means of the natural-scientific inductive method; and an attempt to foresee the future steps of mankind on the road to liberty' (1903:91). Similarly, no claims of universal truth were posited in the conclusion. 'Whether or not Anarchism is right in its conclusions, will be shown by a scientific criticism of its bases and by the practical life of the future. But in one thing it is absolutely right: ... it has forever parted company with metaphysics' (1903:94).

\section{Conclusion}

This article has shown that categories like 'essentialism', 'foundationalism' and similar conceptual tools cannot be generalised or applied without paying enough attention to historical 2017 "Evolution and revolution: anarchist geographies, modernity and post-structuralism", Environment and Planning D-Society and Space, DOI: 10.1177/0263775817694032. Online first: http://journals.sagepub.com/doi/full/10.1177/0263775817694032 
and material contexts. These contexts show that early anarchist geographers were aware of the ideological nature of 'science', and that they tried to use intellectual tools of their time like evolutionism for their political programme. What they challenged were the big 'metanarratives' of state, metaphysics, religions and capitalism; their concrete answer to the problem of voluntary servitude was their commitment to anarchist education, i.e. the complete democratisation of knowledge and research. I have sought to show that they openly contested the ideas of linear progress, racism and European supremacy, as well as the concepts of anthropocentrism, anthropomorphism and the domination of 'man' over 'nature'. Thus, it is hard to make the early anarchist geographers fit simplistic definitions of 'Enlightenment', 'positivism' and 'modernity'.

If Reclus and Kropotkin were very complex figures and often evoked the concepts of modernity and progress, this has not to be confused with a reductionist or Euro-centric idea of modernity. Authors who study anarchist movements outside European cultures, like Maia Ramnath, notice an anarchist exceptionality: 'What is unique about the anarchist tradition ... is its continuous struggle for a synthesis between the two polarities, rejecting neither' (Ramnath, 2012:35). If anarchism does not match any simplistic definition of 'modernity' and 'antimodernity', 'humanism' and 'naturalism', it is also because anarchists were generally ignored by those who elaborated the most updated definitions of these concepts.

Thus, these ideas still have the potential to nourish future debates: I argued above that that the main contributions the anarchist tradition can bring to to-day non-essentialist geographies lies in the ideas of individuality and variety. This was already clear to a historian of anarchism like Max Nettlau, who noticed, concerning Reclus' New Universal Geography, that 'only an anarchist would be able to produce such a work in which millions of particularities are presented in a harmonious order, because he alone possesses the open, flexible mind that is needed to give each problem its due give its own right to any problem, without looking to force it into a specific system’ (Nettlau, 1930:30).

In his most recent book, Newman calls for Stirnerite individualism, definitively excluding the problems of social justice and social change from his project, which draws more 'on the thought of Stirner, Sorel, and La Boétie than it does on Bakunin, Kropotkin and Proudhon... 2017 "Evolution and revolution: anarchist geographies, modernity and post-structuralism", Environment and Planning D-Society and Space, DOI: 10.1177/0263775817694032. Online first: http://journals.sagepub.com/doi/full/10.1177/0263775817694032 
$[\mathrm{P}]$ ostanarchism emphasises an anarchism of the here and now, unencumbered by this revolutionary narrative' (Newman, 2016:XI). It prefers 'autonomous action as pure means without end' (2016:XIII) and the individual is said to be 'already free in an ontological sense, rather than seeing freedom as a universal goal to be attained for humanity' (2016:63); thus, 'political action is no longer determined... by notions of the universal emancipation of mankind' (2016:113), no longer interesting because 'freedom and autonomy are possible in any situation or social arrangement, just as domination is possible in any social arrangement' (2016:130). Supposing that most of the millions who take part today in grassroots movements for justice and social transformation (i.e. the 'revolutionaries') are nothing if not happy to no longer encumber the horizon of 'postanarchists', I would argue that taking into account concepts like freedom and justice (albeit 'metanarratives') still makes some sense for critical geographical scholarship. Finally, I hope I have brought to light some of the contributions that early anarchist geographies might make to these social challenges, providing them with a 'new burst of colour' (Springer, Barker, Brown, Ince and Pickerill, 2012). Dealing with poststructuralist critique does not necessarily imply putting aside the anarchist geographical tradition, as recent scholarship demonstrates (Springer, 2012 and 2016).

\section{References}

Ackelsberg MA (1991) Free women of Spain: anarchism and the struggle for the emancipation of women. Indianapolis: Indiana University press.

Adams M (2015) Kropotkin, Read and the Intellectual history of British anarchism. London: Palgrave.

Angault JC et al. (2014) Le Maitron des Anarchistes. Paris: Les Éditions Ouvrières.

Antliff A (2010) Anarchy, power, and poststructuralism, Anarchist Library http://theanarchistlibrary.org/library/allan-antliff-anarchy-power-and-poststructuralism Antonioli M et al. (2003-2004) Dizionario Biografico degli Anarchici Italiani. Pisa: BFS.

Barclay H (1996) People Without Government, an Anthropology Of Anarchy. London: Kahn and Averill.

Bourdieu P (1975) The specificity of the scientific field and the social conditions of the progress of reason, Social Science Information 14:19-47.

2017 "Evolution and revolution: anarchist geographies, modernity and post-structuralism", Environment and Planning D-Society and Space, DOI: 10.1177/0263775817694032. Online first: http://journals.sagepub.com/doi/full/10.1177/0263775817694032 
Breitbart M (1978) The Theory \& Practice of Anarchist Decentralism in Spain, 1936-1939. Worcester: Clark University (PhD dissertation).

Brun C (2015) Elisée Reclus, une chronologie familiale. Raforum, http://raforum.info/reclus/spip.php?article474\&lang=fr

Call L (2003) Postmodern anarchism. Lanham: Lexingdon Books.

Castree N (1995) The nature of produced nature. Antipode 27(1):12-48.

Cho S, Crenshaw KW and McCall L (2013) Toward a field of intersectionality studies: theory, applications, and praxis, Signs: Journal of Women in Culture and Society 38(4):785-810.

Demeritt D (2002) What is the 'social construction of nature'? A typology and sympathetic critique. Progress in Human Geography 26(6):767-790.

Clark J (2013) The impossible community. London: Bloomsbury.

Clark J and Martin (2013) Anarchy, Geography, Modernity: Selected Writings of Élisée Reclus. Oakland: PM Press.

CNT (1936) Resolution over the Confederal Concept of Libertarian Communism. The Anarchist Library, https://theanarchistlibrary.org/library/the-confederal-concept-of-libertarian-communism Cresswell T (2013) Geographic thought: a critical introduction. Chichester: Wiley-Blackwell.

Day R (2005) Gramsci is dead, anarchist currents in the newest social movements. London: Pluto Press.

Dugatkin L (2011). The prince of evolution: Peter Kropotkin's adventures in science and politics. Charleston: Createspace.

Dunbar G (1978) Élisée Reclus: historian of nature. Hamden: Archon Books.

Eribon D (1993) Michel Foucault. London: Faber.

Faye E (2006) Nazi foundations in Heidegger's work. South Central Review 23(1):55-56.

Featherstone D and Griffin P (2016) Spatial relations, histories from below and the makings of agency: reflections on The Making of the English Working Class. Progress in Human Geography 40(3):375-393.

Ferretti F (2011) The correspondence between Élisée Reclus and Pëtr Kropotkin as a source for the history of geography. Journal of Historical Geography 37:216-222.

Ferretti F (2014) Pioneers in the history of cartography: the Geneva map collection of Élisée Reclus and Charles Perron. Journal of Historical Geography 43:85-95.

2017 "Evolution and revolution: anarchist geographies, modernity and post-structuralism", Environment and Planning D-Society and Space, DOI: 10.1177/0263775817694032. Online first: http://journals.sagepub.com/doi/full/10.1177/0263775817694032 
Ferretti F (2016) “The murderous civilization": anarchist geographies, ethnography and cultural differences in the works of Elie Reclus. Cultural Geographies [early view], http://cgj.sagepub.com/content/early/2016/08/09/1474474016662293.full

Foucault M (1991) Discipline and Punish. New York: Vintage Books.

Gibson-Graham J K (2006) A Postcapitalist Politics. Minneapolis: University of Minnesota Press.

Girón Sierra A (2003) Kropotkin between Lamarck and Darwin: the impossible synthesis. Asclepio, 40(1):189-213.

Girón Sierra A (2005) En la Mesa con Darwin. Evolución y Revolución en el Movimiento Libertario en España (1864-1914). Madrid: CSIC.

Goldman E (1970) Living my life. New York: Dover.

Gould S J (1997) Kropotkin was no crackpot. Natural History 106:12-21.

Graeber D (2004) Fragments of an Anarchist Anthropology. Chicago: Prickly Paradigm Press.

Gramsci A (1975) Quaderni dal Carcere 12-29. Torino: Einaudi.

Haraway D J (2008) When Species Meet. Minneapolis: University of Minnesota Press.

Haraway D (1988) Situated knowledges: the science question in feminism and the privilege of partial perspective. Feminist Studies 14(3):575-599.

Hobsbawm E J (1959) Primitive Rebels: Studies in Archaic Forms of Social Movement. Manchester: Manchester University Press.

Ince A and Barrera de la Torre G (2016) For post-statist geographies. Political Geography 55: $10-19$.

Jun N (2012) Anarchism and political modernity. New York: Continuum.

Kinna R (2016) Kropotkin: Reviewing the Classical Anarchist Tradition. Edinburgh: Edinburgh University Press.

Kropotkin P (1899) Memoirs of a Revolutionist, vol. II. London: Smith, Elder \& Co.

Kropotkin P (1902) Mutual Aid, a Factor in Evolution, London: Heinemann.

Kropotkin P (1903) Modern Science and Anarchism. Philadelphia: The Social Science Club.

Kropotkin P (1924) Ethics, Origins and Development. London: Harrap.

Kuhn G (2009) Anarchism, postmodernity and poststructuralism. In Amster R, DeLeon A, Fernandez LA, Nocella II AJ, Shannon D (eds) Contemporary Anarchist Studies: an Introductory Anthology of Anarchy in the Academy. London: Routledge: 18-25.

2017 "Evolution and revolution: anarchist geographies, modernity and post-structuralism", Environment and Planning D-Society and Space, DOI: 10.1177/0263775817694032. Online first: http://journals.sagepub.com/doi/full/10.1177/0263775817694032 
Latour B (2004) Politics of Nature: How to Bring the Sciences into Democracy. Cambridge: Harvard University Press.

La Vergata A (2009) Colpa di Darwin? Razzismo, Eugenetica e Altri Mali. Turin: UTET.

Levy C (2007) Sovversivismo: the radical political culture of otherness in Liberal Italy. Journal of Political Ideologies 12(2):147-161.

Livingstone DN (2003) Putting Science in its Place, Geographies of Scientific Knowledge. Chicago: Chicago University Press.

Livingstone DN (2005), Science, text and space: thoughts on the geography of reading, Transactions of the Institute of British Geographers 30(4):391-401.

Livingstone DN (2014) Dealing with Darwin, Baltimore: Johns Hopkins University Press.

Lorimer H (2006) Herding memories of humans and animals. Environment and Planning D 24(4):497-518.

Lorimer J (2012) Multinatural geographies for the Anthropocene. Progress in Human Geography 36(5):593-612

Mac Laughlin J (2016) Kropotkin and the Anarchist Intellectual Tradition. London: Pluto.

Malatesta E (2014) The method of freedom: an Errico Malatesta reader. London: AK Press.

May T (1994) The political philosophy of poststructuralist anarchism. University Park: Pennsylvania State University Press.

Metchnikoff L (1886) Revolution and evolution. Contemporary Review, 50:412-437.

Metchnikoff L (1889) La civilisation et les grands fleuves historiques. Paris: Hachette.

Mitchell D (2000) Cultural Geography. Oxford: Blackwell Publishing.

Morris B (2014) A Brian Morris reader. Oakland: PM Press.

Nash M (1975) Mujeres Libres. Barcelona: Tusquets.

Nettlau M (1930) Eliseo Reclus: Vida de un Sabio Justo y Rebelde, Vol. II. Barcelona: Edicciones de la Revista Blanca.

Newman S (2001) From Bakunin to Lacan: Anti-authoritarianism and the Dislocation of Power. Lanham: Lexington books.

Newman S (2010) The Politics of Postanarchism. Edinburgh: Edinburgh University Press.

Newman S (2011) Post-anarchism: a politics of anti-politics. Journal of Political Ideologies 16 (3):313-327.

Newman S (2016) Postanarchism. Cambridge: Polity Press.

2017 "Evolution and revolution: anarchist geographies, modernity and post-structuralism", Environment and Planning D-Society and Space, DOI: 10.1177/0263775817694032. Online first: http://journals.sagepub.com/doi/full/10.1177/0263775817694032 
Olsson G (1987) Abysmal, a Critique of Cartographic Reason. Chicago: Chicago University Press.

Pelletier P (2013) Géographie et Anarchie, Reclus, Kropotkine, Metchnikoff. Paris: Éditions du Monde Libertaire.

Pelletier P (2015) Anarchisme et Cause Animale. Paris: Éditions du Monde Libertaire.

Philo C and Wilbert C (2000) Animal Spaces, Beastly Places: New Geographies of HumanAnimal Relations. London: Routledge.

Puente Amestoy (2013), Libertarian Communism. Hastings: Christiebooks.

Ramnath M (2011) Decolonizing anarchism: an antiauthoritarian history of India's liberation struggle. London: AK Press.

Reclus E (1888) Nouvelle Géographie Universelle, Vol. XIII. Paris: Hachette.

Reclus E (1901) On Vegetarianism. The Humane Review 1(4):316-324.

Reclus E (1905) L'Homme et la Terre, Vol. I. Paris: Librairie universelle.

Reclus E (1908) L'Homme et la Terre, Vol. VI. Paris: Librairie universelle.

Reclus E (2012) Écrits Sociaux. Geneva: Héros-limite.

Rousselle D (2013) Postanarchism and its critics: a conversation with Saul Newman, Anarchist studies 21(2):74-96.

Scott J (2009) The Art of not Being Governed, an Anarchist History of Upland Southeast Asia. New Haven: Yale University Press.

Secord J (2014) Visions of Science. Oxford: Oxford University Press.

Springer S (2014) Human geography without hierarchy. Progress in Human Geography 38(3):402-419.

Springer S (2016) The Anarchist Roots of Geography: Toward Spatial Emancipation. Minneapolis: University of Minnesota Press.

Springer S, Barker A, Brown G, Ince A, Pickerill J (2012) Reanimating anarchist geographies: a new burst of colour. Antipode 44(5):1591-1604.

Springer S, White R, Lopes de Souza M (eds) (2016) The Radicalisation of Pedagogy. Anarchism, Geography and the Spirit of Revolt. New York: Rowman \& Littlefield.

Swyngedouw E (2006) Circulations and metabolisms: (Hybrid) natures and (cyborg) cities. Science as Culture 15(2):105-121.

Tang C (2008) The Geographic Imagination of Modernity. Stanford: Stanford University Press.

2017 "Evolution and revolution: anarchist geographies, modernity and post-structuralism", Environment and Planning D-Society and Space, DOI: 10.1177/0263775817694032. Online first: http://journals.sagepub.com/doi/full/10.1177/0263775817694032 
Turcato D (2015) Making Sense of Anarchism. London: AK Press.

Vuilleumier M (2012) Histoire et Combats. Geneva: Éditions d'en bas.

White RJ (2015) Following in the footsteps of Elisée Reclus: disturbing places of inter-species violence that are hidden in plain sight. In Nocella II AJ, White RJ and Cudworth E (eds) Anarchism and Animal Liberation. Essays on Complementary Elements of Total Liberation. Jefferson: Mc Farland \& Company: 212-230.

Wills J (2008) Mapping class and its political possibilities. Antipode 40(1):25-30.

Withers CWJ (2010) Geography and Science in Britain, 1831-1939: a Study of the British Association for the Advancement of Science. Manchester: Manchester University Press.

2017 "Evolution and revolution: anarchist geographies, modernity and post-structuralism", Environment and Planning D-Society and Space, DOI: 10.1177/0263775817694032. Online first: http://journals.sagepub.com/doi/full/10.1177/0263775817694032 